\title{
Transatlantica
}

Revue d'études américaines. American Studies Journal

\section{Gone With the Covid - Scarlet in Quarantine: An Interview with Sarah Combs}

Sarah Combs and Emmeline Gros

\section{(2) OpenEdition}

1 Journals

\section{Electronic version}

URL: https://journals.openedition.org/transatlantica/14367

DOI: 10.4000/transatlantica.14367

ISSN: 1765-2766

\section{Publisher}

Association française d'Etudes Américaines (AFEA)

\section{Electronic reference}

Sarah Combs and Emmeline Gros, "Gone With the Covid - Scarlet in Quarantine: An Interview with Sarah Combs", Transatlantica [Online], 1 | 2019, Online since 01 July 2020, connection on 02 February 2023. URL: http://journals.openedition.org/transatlantica/14367 ; DOI: https://doi.org/10.4000/ transatlantica. 14367

This text was automatically generated on 2 February 2023.

Creative Commons - Attribution-NonCommercial-NoDerivatives 4.0 International - CC BY-NC-ND 4.0 https://creativecommons.org/licenses/by-nc-nd/4.0/ 


\title{
Gone With the Covid - Scarlet in Quarantine: An Interview with Sarah Combs
}

\author{
Sarah Combs and Emmeline Gros
}

This media file cannot be displayed. Please refer to the online document http:// journals.openedition.org/transatlantica/14367

\section{APPENDIXES}

This media file cannot be displayed. Please refer to the online document http:// journals.openedition.org/transatlantica/14367

\section{ABSTRACTS}

Artist Sarah Combs (https://sarahelizabethcombs.com/) claims that art and laughter have the power to give us some respite from our fears and worries. Laughter can be just the right medicine to forget our troubles. As a family Covid-19 quarantine project, Combs recently created a short film, Gone With the Covid, a spoof of the classic film, Gone With the Wind. Beyond laughter and comic relief, is parody also a conduit of critique, or are certain topics-racism, the legacy of slavery, racial inequalities in epidemics like Covid-19-too serious issues to be parodied? In this 
interview, Sarah Combs explains her motivations and the challenges she had to face in the process.

L'artiste Sarah Combs (https://sarahelizabethcombs.com/) affirme que l'art et le rire ont le pouvoir de nous offrir un répit loin de nos peurs et contrariétés. Le rire peut être le bon remède pour nous faire oublier nos soucis. La quarantaine familiale due à l'épidémie de Covid-19 lui a inspiré un court-métrage, Gone With the Covid, une parodie du film classique du cinéma hollywoodien Gone With the Wind. Par-delà la détente que procure le rire, la parodie est-elle aussi un outil critique ou faut-il parfois s'en abstenir, certains sujets - le racisme, la mémoire de l'esclavage, les inégalités raciales face aux épidémies comme le Covid-19 - étant trop graves pour être parodiés? Dans cet entretien, Sarah Combs nous explique ses motivations et les défis qu'elle a dû relever dans le cadre de ce projet.

\section{INDEX}

Keywords: Mitchell (Margaret), Gone With the Wind, Covid-19, parody, Hollywood cinema, Costco, quarantine, O'Hara (Scarlett), Combs (Sarah)

Mots-clés: Mitchell (Margaret), Autant en emporte le vent, Covid-19, parodie, cinéma hollywoodien, Costco, quarantaine, O'Hara (Scarlett), Combs (Sarah)

\section{AUTHORS}

\section{EMMELINE GROS}

BABEL, Université de Toulon 